\title{
The Utilization by Yeasts of Acids of the Tricarboxylic Acid Gycle
}

\author{
BY J. A. BARNETT \\ Low Temperature Research Station, Cambridge \\ AND H. L. KORNBERG \\ M.R.C. Cell Metabolism Research Unit, Department of \\ Biochemistry, University of Oxford
}

(Received 7 January 1960)

\section{SUMMARY}

Growth and respiration on intermediates of the tricarboxylic acid cycle as sole sources of carbon were studied with a number of different yeasts. The incorporation of $\left[1: 2-{ }^{14} \mathrm{C}\right]$ acetate by acetate-respiring cells was studied with yeasts capable of utilizing exogenously supplied cycle intermediates $(\mathbf{K}+)$ and also with those unable to do so $(K-)$. Enzyme systems were examined by using cell-free extracts. It was concluded that the difference between $\mathbf{K}+$ and $\mathbf{K}$ - yeasts was not one of a major metabolic pathway, but probably of the permeability of the intact cells. Evidence was found for the operation of the tricarboxylic acid cycle in yeasts under differing growth conditions, and for the operation of the glyoxylate cycle in yeasts growing on acetate.

\section{INTRODUCTION}

Various workers have tested the ability of yeasts to utilize acids of the tricarboxylic acid (TCA) cycle. For example, Leberle \& Will (1910) indicated that four strains of Candida mycoderma were probably capable of utilizing succinic and malic acids for growth. Okunuki (1931) reported that species of the genus Rhodotorula and the genus Sporobolomyces seemed able to use citric, succinic and malic acids. In these experiments peptone was present in the growth medium in addition to the organic acid being tested. In 1948, Wickerham \& Burton reported that many yeasts could grow with intermediates of the TCA cycle as sole sources of carbon, utilizing citric, succinic, fumaric and malic acids. Wickerham (1951) described 15 species of the genus Hansenula; strains of 12 of these species were able to grow on citric or succinic acids. Testing with citrate, succinate and malate, Kudriavzev (1954) found that 36 out of 68 species of ascosporogenous yeasts utilized at least succinic acid. Such intermediates of the TCA cycle are now used in routine identification by the Yeast Division of the Centraalbureau voor Schimmelcultures (CBS). Yeasts may thus be divided into two groups: ' $K+$ ', those capable of using as sole carbon source for growth or respiration one or more intermediates of the TCA cycle; ' $\mathrm{K}-$ ', those yeasts unable to do so.

\section{METHODS}

Media. Yeasts were grown in the carbon-free defined medium $\left(\mathbf{A}_{2}\right)$ of Barnett \& Ingram (1955), to which was added respectively, glucose $\left(A_{2} G\right)$, succinate $\left(A_{2} S\right)$, acetate $\left(\mathbf{A}_{2} \mathbf{A c}\right)$ or citrate $\left(\mathbf{A}_{2}\right.$ Cit.) to final concentrations of $1 \%(w / v)$. In addition, Difco Bacto $\mathrm{Y}-\mathrm{M}$ broth and agar were used where indicated. 
Organisms. Stock cultures were maintained at $+1^{\circ}$ on slopes of $\mathrm{Y}-\mathbf{M}$ agar and subcultured every 6 months (cf. Kirsop, 1954). The yeasts were incubated at $25^{\circ}$.

The yeasts came from the following collections: The Yeast Division of the Centraalbureau voor Schimmelcultures, Delft, Holland (CBS); The National Collection of Yeast Cultures, Great Britain (NCYC); The American Type Culture Collection (ATCC); The North Regional Research Laboratories, Peoria, Illinois, U.S.A. (NRRL); The Carlsberg Laboratory, Copenhagen, Denmark (CARL); The Division of Bacteriology and Dairy Research, Department of Agriculture, Ottawa, Canada (DBDR); The Low Temperature Station, Cambridge, England (LTS).

The strain of Saccharomyces drosophilarum, CBS 2896, was received from Professor V. I. Kudriavzev (Institute of Microbiology, Academy of Sciences of the U.S.S.R.) as Zygofabospora krasilnikovi (see Kudriavzev, 1954) and deposited with the CBS.

\section{Growth of yeasts for inocula and suspensions}

For growth experiments. For each growth experiment, a fresh Y-M agar slope was inoculated from the stock culture. After incubation for 2 days, the yeasts were washed off the slope with medium $\mathbf{A}_{2}$ and the entire crop used to inoculate a Roux bottle containing about $100 \mathrm{ml}$. of $A_{2} G$ agar. The cultures were harvested after incubation for 2 days.

For manometric experiments. For each manometric experiment a 2-day culture from a Y-M agar slope was used to inoculate a 1 l. Fernbach culture flask, containing $200 \mathrm{ml}$. medium. These flasks were shaken (at c. 2 cycles/sec.; $5 \mathrm{~cm}$. travel) for $c$. $24 \mathrm{hr}$. at $25^{\circ}$.

For isotope experiments. The suspension of yeast cells was in each case prepared exactly as for manometry; but four Fernbach flask cultures were necessary for each experiment.

For preparation of cell-free extracts. The several grammes of yeast needed in each experiment were grown in a Hoover washing machine adapted for this purpose. The machine consisted of a stainless steel vessel (30 l. capacity) with a mechanical stirrer, and a hole in the bottom of the tank through which sterile air was pumped. A metal top and gasket prevented contamination from the air; heat produced metabolically (Winzler \& Baumberger, 1938) was prevented from increasing the temperature of the medium above that of the thermostatically controlled room by means of a cooling coil. The yeast was grown for $24 \mathrm{hr}$. in media $\mathbf{A}_{2} \mathrm{Ac}, \mathrm{A}_{2} \mathrm{Cit}$, or $\mathbf{A}_{2} \mathrm{~S}$. The crop was harvested with a Sharples Laboratory Super-centrifuge, washed in 101 . of $0.9 \%(w / v)$ potassium chloride, re-centrifuged and stored at $-15^{\circ}$.

\section{Growth experiments}

The methods used were based on those described by Barnett \& Ingram (1955).

Auxanography. Each culture was harvested into $10 \mathrm{ml}$. medium $\mathbf{A}_{2}$ and transferred to a ' 1 oz.' ( $25 \mathrm{ml}$.) screw-capped bottle by means of a sterile pipette. The concentration of cells was checked roughly with a nephelometer and adjusted aseptically to $c .5 \times 10^{8} \mathrm{cells} / \mathrm{ml}$. Of this suspension, $0.5 \mathrm{ml}$. was added to a tube containing $10 \mathrm{ml}$. melted $A_{2}$ agar medium which had been cooled to $48^{\circ}$. The contents of the tube were poured into a Petri dish $(9 \mathrm{~cm}$. diameter) after quick but thorough mixing. The surface of the agar was dried by incubating the dishes, open 
and inverted, at $37^{\circ}$ for $1.5 \mathrm{hr}$. The carbon sources were placed on the surface with a platinum spoon in 2-5 mg. quantities, not more than three test-substances/plate. The auxanograms were incubated and examined every 2 days for a week.

T-tubes. The inocula were prepared exactly as for auxanograms. The suspension of cells was added to $400 \mathrm{ml}$. $A_{2}$ medium contained in a sterile $500 \mathrm{ml}$. Quickfit interchangeable round flask with a flat bottom and short neck, stoppered with a gauze-covered cotton wool plug. This was then attached to a sterile automatic burette, a modification of the inoculating apparatus described by Barnes (1950), for distributing $10 \mathrm{ml}$. inoculated medium into each T-tube. When only a few tests were to be made on any one strain of yeast, smaller quantities were prepared and delivered with $10 \mathrm{ml}$. sterile pipettes.

The carbon-sources were distributed with a sterile pipette to each T-tube to a final concentration of $c .1 \%$. They were made up and stored as $10 \%(\mathrm{w} / \mathrm{v})$ solutions at pH 5.0 and sterilized through a membrane filter. (This apparatus was Model Stefi 4 of Membranfilter Gesellschaft, Göttingen, Germany, and the bacteria-proof membrane their Spezial-Membranfilter Co 5. For distributing the sterile solutions, the filter was set up as recommended for a Seitz filter by Mackie \& McCartney, 1956).

The T-tubes were shaken (c. 2 cyc. $/ \mathrm{sec}, 5 \mathrm{~cm}$. travel) at $25^{\circ}$, readings being taken with an E.E.L. nephelometer at $0,2,4$ and 6 days. The nephelometer used was set to give a reading of $\mathbf{5 2}$ on the scale with the solid standard provided.

\section{Manometric experiments}

For measurements of the oxidation of acetate and of intermediates of the TCA cycle, the centrifuged yeast was suspended in $0 \cdot 1 \mathrm{M}$-potassium phosphate buffer (pH 5.9) and re-centrifuged. The washed yeast was re-suspended in 0.1 $\mathrm{M}$-phosphate buffer, $\mathrm{pH} \mathrm{5.9}$, to a final concentration equivalent to $c .5 \mathrm{mg}$. dry wt./ml. This suspension was placed in a Fernbach flask and shaken again at $25^{\circ}$ for $1 \mathrm{hr}$. in order to decrease the rate of endogenous respiration. The rates of oxygen uptake on addition of substrates were measured with Warburg manometers. Flasks (approx. vol. $20 \mathrm{ml}$.) with single side arms contained $2 \mathrm{ml}$. yeast suspension in the main compartment, and $25 \mu$ mole of the substrates in $0.1 \mathrm{ml}$. water in the side arms. Strips of Whatman no. 40 filter paper and $0.2 \mathrm{ml}$. of $2 \mathrm{~N}-\mathrm{KOH}$ were placed in the centre wells. The gas phase in the manometers was air, and they were equilibrated at $25^{\circ}$ for 10-20 min., and the contents of the side arms mixed with those of the main compartments. Readings were taken at $10 \mathrm{~min}$. intervals and recorded.

\section{Incorporation of $\left[{ }^{14} \mathrm{C}\right]$ acetate by whole yeast cells}

The methods used were based on those described by Kornberg (1958).

Yeast cells which had been centrifuged after growth in Fernbach culture flasks were washed, and re-suspended in $0.9 \%(\mathrm{w} / \mathrm{v}) \mathrm{KCl}$ at a concentration equiv. c. $10 \mathrm{mg}$. dry wt./ml. About $50 \mathrm{ml}$. of the suspension were shaken in a Fernbach flask at $25^{\circ}$ for about $1 \mathrm{hr}$. to lower the rate of endogenous respiration.

Of this suspension, $7 \mathrm{ml}$. were added to $7 \mathrm{ml}$. of $0.2 \mathrm{M}$-phosphate buffer (pH 5.9) in the $100 \mathrm{ml}$. conical Quickfit flask of an automatic pipette. (These pipettes, delivering $\mathbf{1} \pm \mathbf{0} \cdot 1 \mathrm{ml}$., can be obtained from W. G. Flaig and Sons Ltd., 39 Waterloo 
Road, London, N.W. 2.) The pipette flask was partly immersed in a Warburg bath and shaken at $25^{\circ}$.

Two Warburg manometers, operating in the same bath, were used to follow, simultaneously, the rates of respiration of the yeast, one with and the other without substrate. The Warburg flasks (approx. vol. $20 \mathrm{ml}$.), with single side arms, contained $1 \mathrm{ml}$. yeast suspension and $1 \mathrm{ml}$. 0.2 $\mathrm{M}$-phosphate buffer ( $\mathrm{pH} \mathrm{5.9)}$ in the main compartments; and one flask had $25 \mu$ mole sodium acetate in $0.1 \mathrm{ml}$. of water in the side arm. Strips of Whatman no. 40 filter paper and $0 \cdot 2 \mathrm{ml}$. of $2 \mathrm{~N}-\mathrm{KOH}$ were placed in the centre wells. The gas phase in the manometers was air, and they were equilibrated for about 20 min. at $25^{\circ}$. Readings were taken at 5 min. intervals and recorded.

The contents of the Warburg flask side arm were mixed with those of the main compartment, and at the same moment $175 \mu$ mole of sodium acetate in $0.5 \mathrm{ml}$. water were added to the pipette flask and the contents well mixed.

When the rate of acetate oxidation was steady (usually after about $20 \mathrm{~min}$.) the automatic pipette was removed from the bath, $0.5 \mathrm{ml}$. $\left[1: 2-{ }^{14} \mathrm{C}\right]$ acetate solution (prepared by mixing equal portions of $\left[1^{-14} \mathrm{C}\right]$ and $\left[2-{ }^{14} \mathrm{C}\right]$ acetate, and containing 18.5 $\mu$ mole of acetate, $100 \mu \mathrm{c}$, and giving $6.5 \times 10^{6} \mathrm{counts} / \mathrm{min}$. under the conditions of radio-assay used) was added and the top of the pipette replaced. After rapid manual swirling of the contents to ensure good mixing, a $1 \mathrm{ml}$. sample was pipetted into a centrifuge tube standing in ice. At intervals after adding the radioactive acetate further samples were removed and the time was recorded to the nearest second. Each sample was centrifuged immediately at $c .20,000 \mathrm{~g}$ at $-3^{\circ}$ for $c .30 \mathrm{sec}$. and the supernatant fluids discarded. (These supernatant fluids did not contain a significant quantity of ethanol-soluble and non-volatile radioactive material. This procedure eliminated interference from radiation decomposition products; the latter, forming $0.05-0.1 \%$ of the total radioactivity of acetate (cf. Kornberg, 1958), evidently did not penetrate the cells.)

Preparation of aqueous ethanolic extracts. To the packed cells was rapidly added $1 \mathrm{ml}$. of absolute ethanol; the suspension was stirred well and re-centrifuged. The clear supernatant solutions were poured into thick-walled Pyrex tubes and the precipitates were resuspended, each in $1 \mathrm{ml} .20 \%(\mathrm{v} / \mathrm{v})$ ethanol in water. After recentrifuging the corresponding supernatant solutions were combined and evaporated to dryness at $c .60^{\circ}$ under a stream of nitrogen. The dry material was resuspended in $0.5 \mathrm{ml}$. of $20 \%(\mathrm{v} / \mathrm{v})$ ethanol in water, and samples thereof $(0.1$ or $0.2 \mathrm{ml}$.) were analysed by chromatography and radioautography as previously described (Kornberg, 1958).

\section{Experiments with cell-free extracts}

Preparation of extracts. Frozen cells were crushed in a Hughes Press (Hughes, 1951) without using abrasive. The crushed yeast was mixed with 9 vol. of $0.9 \%$ $(\mathrm{w} / \mathrm{v}) \mathrm{KCl}$ and homogenized in a glass homogenizer (Umbreit, Burris \& Stauffer, 1949). The homogenate was centrifuged at $c .20,000 \mathrm{~g}$ at $-3^{\circ}$ for $5 \mathrm{~min}$., and the supernatant solution used for the experiment.

The acetic thiokinase activity of the supernatant solutions was measured by the method of Jones \& Lipmann (1955).

Malate synthetase activity. In early experiments this was measured as the quantity 
of isotope incorporated into malate when cell extracts were incubated with $\left[{ }^{14} \mathrm{C}\right]$ acetate, $\mathrm{MgCl}_{2}$, glutathione, coenzyme $\mathrm{A}$, adenosine triphosphate (ATP) and glyoxylate (Kornberg \& Madsen, 1958; see below). In later experiments, the activity of the enzyme was measured by the optical procedure of Dixon \& Kornberg (1959).

Isocitratase activity was determined by the assay of glyoxylate (Friedemann \& Haugen, 1943) formed by the cleavage of isocitrate (see Kornberg \& Madsen, 1957), the identity of the keto compound being confirmed by chromatography of the 2:4dinitrophenylhydrazones (El Hawary \& Thompson, 1953). The development of more direct assay procedures (Dixon \& Kornberg, 1959) allowed quantitative determinations to be made during later parts of this work.

Incorporation of $\left[{ }^{14} \mathrm{C}\right]$ acetate by cell-free extracts. The methods used for studying the incorporation of labelled acetate by cell-free extracts were modified from those described by Kornberg \& Madsen (1958). The incubation mixture contained $100 \mu$ mole potassium phosphate ( $\mathrm{pH} 7 \cdot 5$ ), $10 \mu$ mole reduced glutathione, $10 \mu$ mole $\mathrm{MgCl}_{2}, 10 \mu$ mole ATP, $0.08 \mu$ mole coenzyme A (Sigma Chemical Co., St Louis, Missouri, U.S.A.), $0 \cdot 1 \mathrm{ml}$. of crushed yeast extract, $1.9 \mu$ mole $\mathrm{CH}_{3}{ }^{14} \mathrm{COONa}$ (containing $10 \mu$ c. ${ }^{14} \mathrm{C}$; giving $6.5 \times 10^{5}$ counts $/ \mathrm{min}$.), $10 \mu$ mole unlabelled potassium acetate. The quantities of other unlabelled substrates, added as indicated, were as follows: $10 \mu$ mole sodium oxaloacetate; $10 \mu$ mole sodium glyoxylate; $40 \mu$ mole $\mathrm{DL}+$ allo isocitrate (potassium salt); $20 \mu$ mole sodium pyruvate; $0.4 \times 10^{-3} \mu$ mole diphosphopyridine nucleotide. Water was added to $1 \mathrm{ml}$. After incubation at $30^{\circ}$ for $30 \mathrm{~min}$., the reaction in each tube was stopped by adding $3 \mathrm{ml}$. hot absolute ethanol. The $\mathbf{7 5} \%(\mathrm{v} / \mathrm{v})$ ethanolic aqueous suspensions were centrifuged at $c .250 \mathrm{~g}$, the precipitates washed with $1 \mathrm{ml} .20 \%(\mathrm{v} / \mathrm{v})$ ethanol in water and the combined supernatant solutions evaporated to dryness at $c .60^{\circ}$ under a stream of nitrogen. The chromatographic-autoradiographic analysis was carried out as described by Kornberg (1958).

Protein estimation. The protein content of each yeast extract was estimated by nephelometric-turbidity measurements of trichloro-acetic acid precipitates (Stadtman, Novelli \& Lipmann, 1951). A standard curve was obtained by using Armour's bovine serum albumin as a standard. For the estimations, $0.2 \mathrm{ml}$. of the yeast extract was added to $1.8 \mathrm{ml}$. water; to this $3 \mathrm{ml}$. of $5 \%(w / v)$ trichloro-acetic acid was added, and the turbidity measured.

\section{RESULTS}

\section{Growth experiments}

The results for the $\mathbf{K}+$ yeasts are summarized in Table $\mathbf{1}$. The yeasts listed below were found unable to grow on citrate, fumarate, malate or succinate as sole sources of carbon. The response to acetate, where tested, is indicated in brackets: [+] growth, [-] no growth. Kloeckera apiculata (LTS 5); Saccharomyces acidifaciens (CBS 749, DEDR 427, ATCC 8766, CBS 685, NRRL Y54, ATCC 2602, CBS 1085); S. bailii (CBS $680[+]$ ); S. bisporus (CBS 702 [+]); S. cerevisiae (NCYC 77 [+], NCYC 231 [+], NCYC 176 [+], CARL 53, LTS 4); S. cerevisiae var. ellipsoideus (NCYC 93 [+], NCYC 94 [+], CBS 818 [-]); S. delbrueckii var. mongolicus (CBS 705); $S$. fermentati (NCYC 161); $S$. mellis (CBS 736, CBS 684, DBDR Z7, CBS 737, CBS 742, DBDR M1); $S$. pastori (CBS 704); S. rosei (CBS 728); S. rouxii (LTS 16, 
LTS 17, LTS 18, CBS 710, CBS 781, CBS 732, ATCC 2623, CBS 682, CBS 687, CBS 688, CBS 686, DBDR Z5, CBS 738, CBS 741, ATCC 4898, DBDR Y 139, ATCC 2619, DBDR Z1); S. rouxii var. polymorphus (CBS 711, DBDR Z3, NCYC 170, DBDR Z4, DBDR 58, CBS 678, CBS 706, CBS 784, ATCC 2624, DBDR Z2, CBS 727, CBS 713, CBS 726, ATCC 2617). These data suggest the following two generalizations. First, $\mathbf{K}+$ yeasts (capable of utilizing TCA cycle intermediates) include those tested which Wickerham (1955; Wickerham \& Burton, 1956a, b)

Table 1. Results of growth tests on TCA cycle intermediates as substrates: $\boldsymbol{K}+$ yeasts

\begin{abstract}
Auxanograms. For each auxanogram, a suspension of c. $2.5 \times 10^{3}$ yeast cells in $0.5 \mathrm{ml}$. of water was added to a tube containing $10 \mathrm{ml}$. melted agar medium without carbon source, at $48^{\circ}$. After mixing, the medium was poured into a Petri dish, cooled, and the surface dried in an incubator. Test carbon sources were placed on the agar surface of each plate, which was incubated and examined every 2 days for a week. T-tubes. Each T-tube contained initially $10 \mathrm{ml}$. of carbon-free liquid medium, $1 \%(\mathrm{w} / \mathrm{v})$ of carbon source, yeast cells to give an initial nephelometer reading ('zeroed' at 52) of $c$. 10. The T-tubes were shaken at $25^{\circ}$ and nephelometer readings taken at $0,2,4$ and 6 days. Symbols. The letter ' $A$ ' indicates that the auxanographic method was used: in all other cases T-tubes were employed. $\mathbf{C}=$ citrate; $\mathbf{F}=$ fumarate; $\mathbf{M}=$ malate; $\mathbf{S}=$ succinate $;$ Ac = acetate. $-<10,+10-20,++>20$ (difference between initial and final nephelometer reading). The auxanographic responses are given in terms of + (growth) and - (no growth).
\end{abstract} nt $=$ not tested.

CBS name

Candida krusei

C. utilis

Debaryomyces kloeckeri

Hansenula anomala

H. suaveolens

Pichia membranaefaciens

Rhodotorula flava

Saccharomyces drosophilarum

S. fermentati

S. florentinus

S. lactis

S. marxianus

NCYC 243

CBS 745

CBS 712

Strains

CBS 2066

NCYC 359

LTS 1

CBS 1981, CBS 2576, CBS 2577

NCYC 57

NCYC 54, CBS 240

NCYC 69

CBS 2896

CBS 748

CBS 746, NCYC 172

CBS 739

CBS 683

CBS 743

NCYC 111

CBS 744
Substrate

\begin{tabular}{|c|c|c|c|c|c|}
\hline & \multicolumn{5}{|c|}{ Substrate } \\
\hline & $\mathbf{C}$ & $\mathbf{F}$ & $\mathbf{M}$ & $\mathbf{S}$ & Ac \\
\hline & ++ & ++ & ++ & ++ & $+t$ \\
\hline $\boldsymbol{A}$ & + & + & + & + & nt \\
\hline & ++ & ++ & ++ & ++ & - \\
\hline & ++ & ++ & ++ & ++ & ++ \\
\hline & - & ++ & ++ & ++ & ++ \\
\hline $\boldsymbol{A}$ & - & + & - & + & nt \\
\hline & - & ++ & + & + & - \\
\hline & ++ & ++ & ++ & ++ & ++ \\
\hline $\boldsymbol{A}$ & - & + & - & + & nt \\
\hline & - & - & + & ++ & - \\
\hline$A$ & - & + & - & + & nt \\
\hline & - & + & - & + & nt \\
\hline & - & - & - & ++ & ++ \\
\hline $\boldsymbol{A}$ & - & + & - & + & nt \\
\hline & - & - & ++ & ++ & nt \\
\hline $\boldsymbol{A}$ & - & + & - & + & nt \\
\hline & - & - & - & + & ++ \\
\hline & + & + & + & ++ & ++ \\
\hline $\boldsymbol{A}$ & - & + & - & + & nt \\
\hline & - & + & ++ & ++ & ++ \\
\hline $\boldsymbol{A}$ & - & + & - & + & nt \\
\hline & + & - & + & + & nt \\
\hline $\boldsymbol{A}$ & $\begin{array}{c}+ \\
++\end{array}$ & $\begin{array}{l}+ \\
+\end{array}$ & $\begin{array}{c}+ \\
++\end{array}$ & $\begin{array}{c}+ \\
++\end{array}$ & $\begin{array}{l}\text { nt } \\
\text { nt }\end{array}$ \\
\hline & ++ & + & + & ++ & - \\
\hline
\end{tabular}


placed in the group 'Dekkeromyces' or Kudriavzev (1954) in the group 'Fabospora' (and 'Zygofabospora'); these were Saccharomyces drosophilarum, S. lactis, and $S$. marcianus. Secondly, K-yeasts include $S$. acidifaciens, $S$. cerevisiae and some of the Saccharomyces most able to tolerate high concentrations of sugar, such as $S$. mellis and $S$. rouxii (e.g. Ingram, 1958). In these experiments, all the $\mathbf{K}+$ yeasts were capable of using succinate; of the other TCA cycle intermediates, citrate was used least often. A minority of $\mathbf{K}+$ and $\mathbf{K}-$ strains did not grow on acetate.
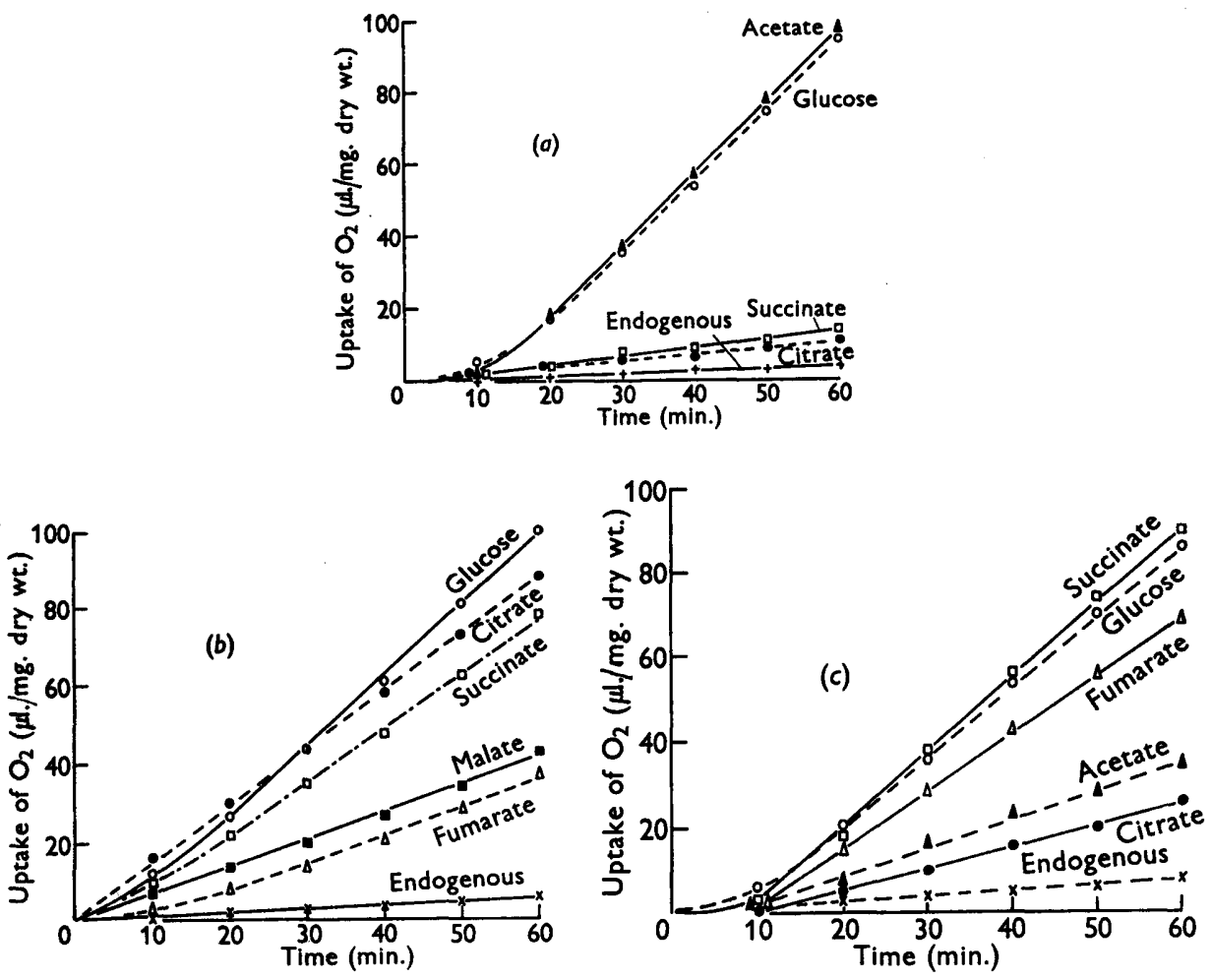

Fig. 1. Oxidation of tricarboxylic acid cycle intermediates by Saccharomyces maraianus (CBS 712) grown on (a) acetate, (b) citrate, and (c) succinate as the sole source of carbon. Manometer flasks contained: washed yeast in $2 \mathrm{ml}$. of $0.1 \mathrm{~m}-\mathrm{phosphate}$ buffer (pH 5.9) in the main compartments; $25 \mu$ mole substrate (as indicated) in $0.1 \mathrm{ml}$. water in the side bulbs; $0.2 \mathrm{ml}$. of $2 \mathrm{~N}-\mathrm{KOH}$ with filter paper in each centre well. Incubated in air at $25^{\circ}$; substrates added at zero time.

\section{Manometric experiments}

The results of the measurements of the oxidation of TCA cycle intermediates are summarized in Table 2. Curves showing the course of oxidation in certain cases are given in Fig. 1. These experiments showed that a number of yeasts of different genera were capable of respiring acetate and intermediates of the TCA cycle at rates comparable to that at which they oxidized glucose. Yeasts grown on acetate tended to respire TCA cycle intermediates only very slowly, as compared with those cultivated on succinate. Two strains, Sacharomyces cerevisiae (NCYC 231) and 
S. acidifaciens (CBS 749), which did not grow on TCA cycle intermediates, were also unable to respire citrate, succinate or fumarate.

Thus, generally, yeasts able to grow on TCA cycle intermediates could respire them too, and conversely. A case of special interest, therefore, is the behaviour of Saccharomyces drosophilarum, CBS 2896, which had been grown on citrate as sole carbon source. These citrate-grown cells, unlike those of $S$. marxianus, CBS 712, not only respired other TCA cycle intermediates particularly slowly, but seemed unable to respire citrate itself (Table 2). When washed citrate-grown cells were resuspended in citrate medium of the kind in which they had been grown, the rate of respiration was indistinguishable from that of the negative-control cells to which no substrate had been added. However, a growing $12 \mathrm{hr}$. culture, concentrated by centrifugation

\section{Table 2. Rates of respiration on TCA cycle intermediates as substrates}

Manometer flasks contained washed yeast cells in $2 \mathrm{ml}$. of $0 \cdot 1 \mathrm{M}$-phosphate buffer, pH 5.9, in the main compartments; $25 \mu$ mole of substrates (as indicated) in $0.1 \mathrm{ml}$. of water in the side bulbs; and $0.2 \mathrm{ml}$. of $2 \mathrm{~N}-\mathrm{KOH}$ with filter paper in each centre well. Incubated in air at $25^{\circ}$. The figures for $Q_{O_{2}}$ have not been corrected for endogenous respiration. $24 \mathrm{hr}$. cultures were used, unless otherwise indicated. Abbreviations: $\mathbf{G}=$ glucose $; \mathbf{A c}=$ acetate $; \mathbf{C}=$ citrate $\mathbf{S}=$ succinate; $\mathbf{F}=$ fumarate $; \mathbf{M}=$ malate END = no carbon substrate.

$Q_{\mathrm{O}_{\mathrm{g}}}:$ Uptake of oxygen ( $\mu \mathrm{l} . / \mathrm{mg}$. dry wt. of yeast/hr.)

\begin{tabular}{|c|c|c|c|c|c|c|c|c|}
\hline \multirow[b]{2}{*}{ Yeast } & \multirow[b]{2}{*}{ Growth medium } & \\
\hline & & $\mathbf{G}$ & Ac & $\mathbf{C}$ & $\mathbf{S}$ & $\mathbf{F}$ & $\mathbf{M}$ & END \\
\hline \multirow{9}{*}{$\begin{array}{l}\text { Saccharomyces } \\
\text { drosophilarum CBS } 2896\end{array}$} & $\mathbf{Y}-\mathbf{M}$ & 174 & 110 & 15 & 44 & 7 & 28 & $\mathbf{5}$ \\
\hline & & 148 & $\mathbf{5 1}$ & 12 & 68 & 8 & 8 & 6 \\
\hline & $\mathbf{A}_{2}$ glucose & 38 & - & 4 & 11 & 4 & 2 & $\mathbf{3}$ \\
\hline & $\mathbf{A}_{2}$ acetate & 74 & 66 & 11 & $\mathbf{3}$ & 4 & . & 4 \\
\hline & & 128 & 130 & 41 & 24 & 17 & $\cdot$ & $\mathbf{1 5}$ \\
\hline & $\mathbf{A}_{2}$ citrate & 69 & 61 & 9 & 14 & 9 & $\dot{0}$ & 6 \\
\hline & & 86 & 48 & 7 & 17 & $\cdot$ & 12 & 7 \\
\hline & $\mathbf{A}_{2}$ succinate & 103 & $\dot{0}$ & 10 & 173 & 58 & 107 & 4 \\
\hline & & 136 & 67 & 17 & 77 & $\mathbf{3 4}$ & $\cdot$ & 12 \\
\hline \multirow[t]{9}{*}{ S. marxianus CBS 712} & $\mathbf{Y}-\mathbf{M}$ & 111 & . & 14 & 14 & 14 & 14 & 11 \\
\hline & & 104 & . & - & 19 & 15 & 15 & 13 \\
\hline & $\mathbf{A}_{2}$ glucose & 112 & - & $\therefore$ & 29 & 10 & 49 & 4 \\
\hline & & 78 & - & 23 & 14 & $\mathbf{9}$ & $\mathbf{3}$ & 4 \\
\hline & $\mathbf{A}_{2}$ acetate & 125 & 125 & 10 & 13 & 7 & $\dot{0}$ & 5 \\
\hline & & 88 & 87 & 25 & 11 & $\cdot$ & 20 & 7 \\
\hline & $A_{2}$ citrate (48 hr.) & 116 & - & 91 & 98 & 45 & 46 & 5 \\
\hline & $\mathbf{A}_{2}$ succinate & 150 & 155 & 134 & 166 & 158 & 120 & 7 \\
\hline & & 140 & $\cdot$ & 133 & 134 & 128 & 112 & 9 \\
\hline \multirow[t]{3}{*}{ Candida krusei CBS 2066} & $\mathbf{Y}-\mathbf{M}$ & 64 & 76 & 17 & $\mathbf{3 0}$ & 13 & 17 & 13 \\
\hline & $\mathbf{A}_{2}$ succinate & 11 & 4 & $\mathbf{2}$ & $\mathbf{2 4}$ & 10 & $\cdot$ & $\mathbf{2}$ \\
\hline & $A_{2}$ acetate & 33 & $\cdot$ & $\mathbf{5}$ & 10 & 5 & $\cdot$ & 6 \\
\hline \multirow{3}{*}{$\begin{array}{l}\text { Hansenula anomala } \\
\text { CBS } 1981\end{array}$} & $\mathbf{Y}-\mathbf{M}$ & 97 & 78 & 43 & 31 & 15 & 15 & 9 \\
\hline & $A_{2}$ acetate $(48 \mathrm{hr})$. & 13 & $\mathbf{2 4}$ & $\mathbf{2}$ & 1 & 1 & $\cdot$ & 2 \\
\hline & $\mathbf{A}_{2}$ succinate & $\mathbf{3 1}$ & 10 & $\mathbf{3 0}$ & 26 & 17 & $\cdot$ & 6 \\
\hline $\begin{array}{l}\text { Saccharomyces cerevisiae } \\
\text { NCYC } 281\end{array}$ & $\mathbf{A}_{2}$ acetate & 102 & 77 & 4 & $\mathbf{3}$ & $\mathbf{3}$ & - & $\mathbf{3}$ \\
\hline S. acidifaciens CBS 749 & $\mathbf{A}_{2}$ acetate & 90 & 78 & 4 & 6 & 5 & $\cdot$ & 6 \\
\hline
\end{tabular}


to equiv. $2 \cdot 7 \mathrm{mg}$. dry wt. yeast $/ \mathrm{ml}$. $\mathrm{A}_{2}$ Cit. medium (but the cells not washed, and the medium not changed), gave a $Q_{o_{2}}$ of 150 and an R.Q. of 1.7. A comparable situation was reported by Cabelli (1955) for Klebsiella pneumoniae. It is possible that washing the cells impaired their ability to oxidize citrate through the removal of a necessary co-factor.

\section{Incorporation of $\left[1: 2-{ }^{14} \mathrm{C}\right]$ acetate by whole cells}

In six experiments, the incorporation of ${ }^{14} \mathrm{C}$ from labelled acetate by whole cells was studied. Of these experiments, two were carried out with succinate-grown Saccharomyces drosophilarum (CBS 2896), one with this yeast grown on acetate, one with it grown on citrate, and one each with $S$. cerevisiae (NCYC 231) and S. acidifaciens (CBS 749) grown on acetate. The results of experiments performed under comparable conditions were similar; those obtained with $\boldsymbol{S}$. drosophilarum are shown in Fig. 2. After addition of labelled acetate to the respiring yeast, ${ }^{14} \mathrm{C}$ was rapidly and linearly incorporated into the fractions soluble in aqueous ethanol. At the earliest times, isotope appeared only in intermediates of the TCA cycle and in amino acids derived from them. The labelling patterns (Fig. $2 a$ ) observed with the yeast grown on succinate (and citrate) are consistent with those expected from the operation of the TCA cycle. This is not so for the acetate-grown yeasts (Fig. $2 b$ ). In particular, the proportions of isotope present in succinate and malate indicate that, at the earliest times, ${ }^{14} \mathrm{C}$ from acetate entered malate without passing through the stage of succinate. Whilst, during the later part of the experiment, succinate contained significantly more ${ }^{14} \mathrm{C}$ than did malate (indicating that the 'pool size' of succinate was greater than than of malate), the succinate in the earliest samples contributed less to the total radioactivity than did malate. The ratio ${ }^{14} \mathrm{C}$ incorporated into malate: ${ }^{14} \mathrm{C}$ incorporated into succinate rose with time in the succinate-grown yeast, which is consistent with the expected formation of labelled malate from labelled succinate (Table 3), but decreased with time in acetate-grown cells. This indicates that, in the acetate-grown cells, labelled succinate could not have been the sole precursor of labelled malate, but that pathways must operate whereby ${ }^{14} \mathrm{C}$ from acetate can enter malate without passing first through succinate.

These results, which are similar to those reported for Pseudomonas fluorescens (Kornberg, 1958), offer presumptive evidence that acetate is utilized by the acetategrown yeast via the concerted action of the tricarboxylic acid and glyoxylate cycles (see Kornberg \& Krebs, 1957), but that this latter cycle does not operate in yeasts grown on succinate.

\section{Experiments with cell-free extracts}

Measurements of acetate-activation. The results of assaying the activity of acetic thiokinase in extracts of the yeasts are shown in Table 4. The extracts from Saccharomyces drosophilarum (CBS 2896) grown on acetate or succinate, and S. acidifaciens (CBS 749) and S. cerevisiae (NCYC 231) grown on acetate were each capable of forming about $2 \mu$ mole acethydroxamic acid $/ \mathrm{mg}$. protein $/ \mathrm{hr}$. from acetate under the test conditions of Jones \& Lipmann (1955).

Measurements of isocitratase activity. Measurements of the rate of glyoxylate production from isocitrate in extracts from the same yeasts are shown in Table 5. Saccharomyces drosophilarum (CBS 2896) grown on acetate as sole carbon source 

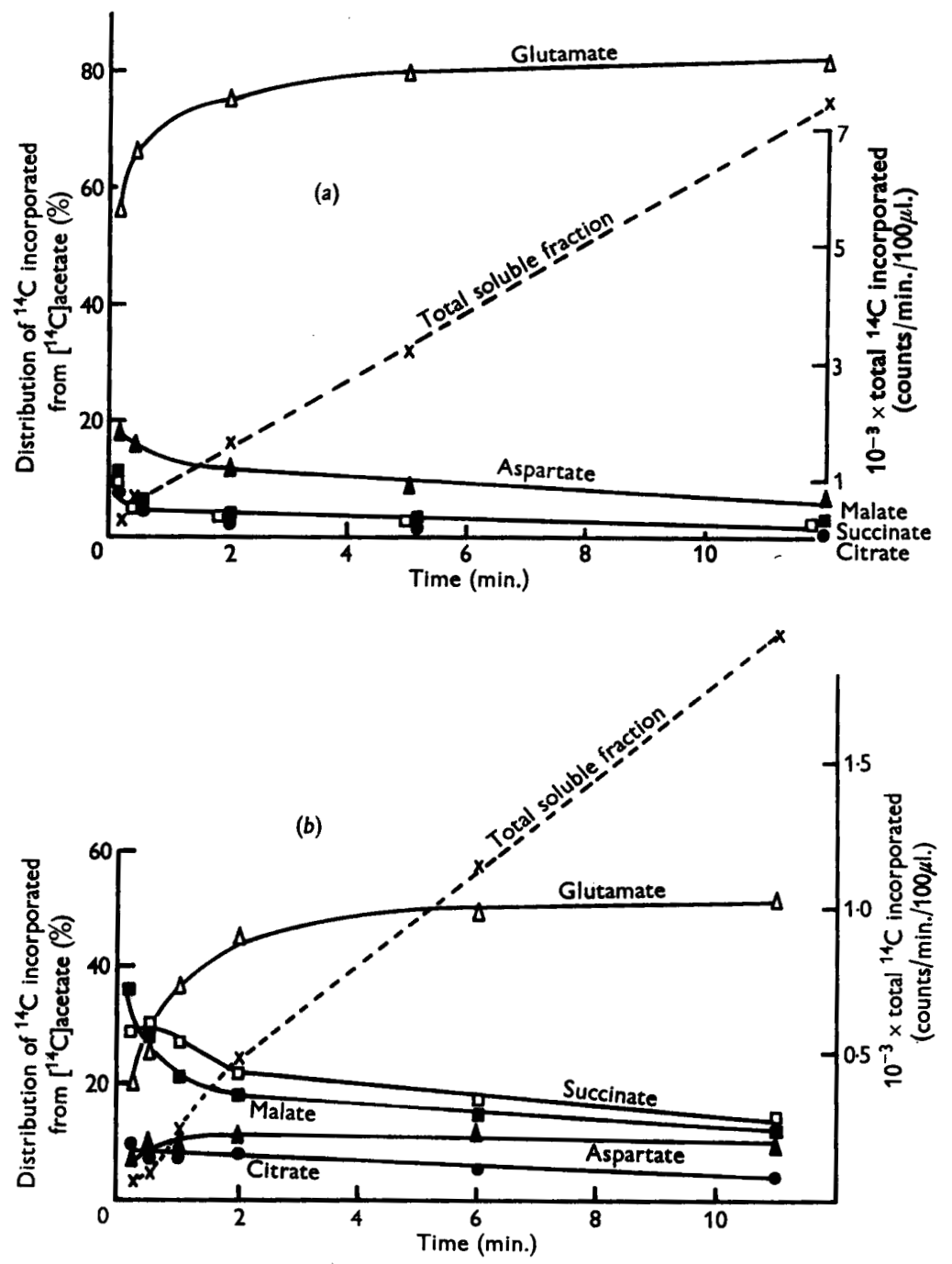

Fig. 2. Incorporation of ${ }^{14} \mathrm{C}$ from $\left[1: 2^{-14} \mathrm{C}\right]$ acetate into the ethanol-soluble fractions of Saccharomyces drosophilarum (CBS 2896) respiring acetate: (a) succinate-grown, (b) acetate-grown. A solution of ${ }^{14} \mathrm{CH}_{\mathrm{a}} \cdot{ }^{14} \mathrm{CO}_{2} \mathrm{Na}$, containing $18.5 \mu$ mole acetate and $100 \mu \mathrm{c}$. of ${ }^{14} \mathrm{C}$, was added at zero time to $14 \mathrm{ml}$. of a suspension of the succinate- or acetate-grown yeast, respiring in an automatic pipette on $12.5 \mathrm{~mm}$-sodium acetate. Samples (approx. $1 \mathrm{ml}$.) were pipetted at known times into tubes standing in ice. The precipitates were each treated with $1 \mathrm{ml}$. of absolute ethanol, and each precipitate washed with $1 \mathrm{ml}$. of $20 \%(v / v)$ aqueous ethanol. The corresponding supernatant solutions were combined and evaporated to dryness under $N_{2}$, resuspended in $20 \%(v / v)$ aqueous ethanol and analysed by two-dimensional paper chromatography. The radioactive compounds were located by radioautography, and the ${ }^{14} \mathrm{C}$ content was determined by direct radioassay of the radioactive areas with a mica end-window $\beta$-counter tube. Each point on the graphs represents the mean of two chromatograms. 
Table 3. Change with time of the ratio of the amount of isotope in succinate to that in malate for respiring suspensions of acetate- and succinate-grown Saccharomyces drosophilarum (CBS 2896) incubated with sodium [1:2-14 C]acetate

Conditions were similar to those described in Fig. 2.

\begin{tabular}{|c|c|c|}
\hline $\begin{array}{c}\text { Carbon source } \\
\text { for growth of } \\
\text { suspensions }\end{array}$ & $\begin{array}{l}\text { Time } \\
\text { (sec.) }\end{array}$ & $\begin{array}{c}\text { Ratio: } \\
\text { 14C incorporated into malate } \\
\text { C } \text { incorporated into succinate }\end{array}$ \\
\hline Succinate & $\begin{array}{r}9 \\
24 \\
120 \\
800 \\
787\end{array}$ & $\begin{array}{l}1 \cdot 0 \\
1 \cdot 1 \\
0 \cdot 81 \\
1 \cdot 3 \\
1 \cdot 6\end{array}$ \\
\hline Acetate & $\begin{array}{r}10 \\
30 \\
60 \\
120 \\
\mathbf{3 6 0} \\
660\end{array}$ & $\begin{array}{l}1.2 \\
1.0 \\
0.82 \\
0.78 \\
0.94 \\
0.84\end{array}$ \\
\hline
\end{tabular}

Table 4. Acetic thiokinase activity of cell-free extracts

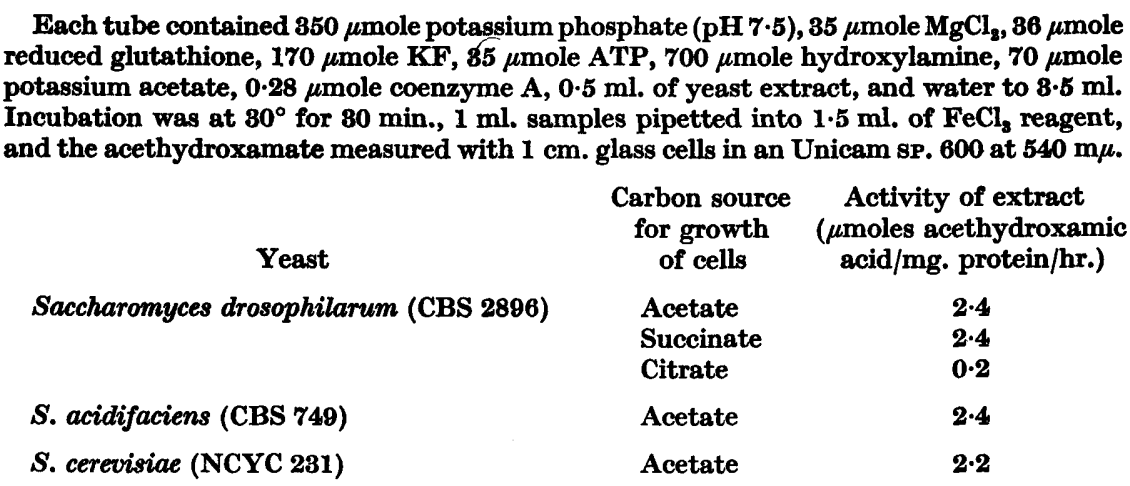

readily formed glyoxylate from isocitrate, the specific activity of the enzyme in the crude cell extract was $15.5 \mu$ mole glyoxylate formed $/ \mathrm{mg}$. soluble protein $/ \mathrm{hr}$., as estimated by the method of Dixon \& Kornberg (1959). The corresponding specific activity for extracts of succinate-grown cells was $0 \cdot 56$, for those grown on citrate 0.55 . Acetate-grown S. acidifaciens (CBS 749) and S. cerevisiae (NCYC 231) gave an activity of a half and a quarter, respectively, of that of acetate-grown $S$. drosophilarum.

These differences in the measured rates of glyoxylate formation from isocitrate by extracts obtained from Saccharomyces drosophilarum grown on succinate, citrate or acetate as carbon sources, were also strikingly confirmed by visual examination of the 2:4-dinitrophenylhydrazones of the keto acids formed under these conditions (Fig. 3). All the extracts from $S$. drosophilarum produced, from added isocitrate, $\alpha$-ketoglutarate and a small quantity of pyruvate; only the extract of the acetategrown yeast, however, catalysed in addition the formation of appreciable amounts of glyoxylate. 
Measurements of malate synthetase activity. Extracts from Saccharomyces drosophilarum (CBS 2896) grown on acetate had a malate synthetase activity under the conditions of assay of $16 \cdot 8 \mu$ mole acetyl $\mathrm{CoA}$ split/mg. soluble protein $/ \mathrm{hr}$. The corresponding figures for extracts of the yeast grown on succinate and citrate were $4 \cdot 3$ and $4 \cdot 2$ (Table 5).

\title{
Table 5. Isocitratase and malate synthetase in extracts of Saccharomyces drosophilarum (CBS 2896)
}

\begin{abstract}
Extracts were prepared by crushing the yeast, grown on acetate, succinate or citrate as sole carbon sources, in a Hughes press, and homogenizing the crushed material with equal volumes of $0 \cdot 1 \mathrm{M}$ potassium phosphate, pH 7.5. To each ml. of these suspensions were added $0 \cdot 1 \mathrm{ml}$. of $2 \%$ protamine sulphate. The precipitates were removed by centrifugation. The isocitratase activity of the clear supernatant solution was estimated as the rate of change of optical density at $324 \mathrm{~m} \mu$ when the extracts were incubated with $200 \mu$ mole potassium phosphate, pH 6.9, $6 \mu$ mole cysteine hydrochloride, $20 \mu$ mole magnesium chloride, $5 \mu$ mole phenylhydrazine hydrochloride, $5 \mu$ mole potassium $L_{8}-i s o-$ citrate and water to $3 \mathrm{ml}$. Malate symthetase was determined by the rate of decrease of optical density at $232 \mathrm{~m} \mu$ resulting from the enzymic removal of acetyl coenzyme $A$ in the presence of glyoxylate (Dixon \& Kornberg, 1959). The ratios $A$ and $B$ were calculated from the data in Table 6, ratio $C$ from those in this table.
\end{abstract}

\begin{tabular}{|c|c|c|c|c|c|c|}
\hline \multirow{4}{*}{$\begin{array}{l}\text { Carbon } \\
\text { source for } \\
\text { growth }\end{array}$} & \multirow{4}{*}{$\begin{array}{l}\text { Protein } \\
\text { concn. of } \\
\text { original } \\
\text { extract } \\
\text { (mg./ml.) }\end{array}$} & \multirow{2}{*}{\multicolumn{2}{|c|}{$\begin{array}{c}\begin{array}{c}\text { Specific activity } \\
\text { ( } \mu \text { moles reacting } / \mathrm{mg} . \\
\text { protein } / \mathrm{hr} .) \text { of }\end{array} \\
\text {. }\end{array}$}} & \multicolumn{3}{|c|}{ Ratio } \\
\hline & & & & & $\boldsymbol{B}$ & $C$ \\
\hline & & & Malate & Condensing enzyme & Condensing enzyme & Malate synthetas \\
\hline & & isoCitratase & synthetase & Malate synthetase & isoCitratase & isoCitratase \\
\hline Acetate & 18 & $15 \cdot 5$ & $16 \cdot 8$ & 0.85 & $1 \cdot 13$ & 1.08 \\
\hline Succinate & $14 \cdot 8$ & 0.56 & $4 \cdot 3$ & $\mathbf{2 \cdot 4 7}$ & $34 \cdot 8$ & $7 \cdot 7$ \\
\hline Citrate & 28 & 0.55 & $4 \cdot 2$ & $\mathbf{2 \cdot 3 0}$ & $\mathbf{3 3 \cdot 2}$ & $7 \cdot 6$ \\
\hline
\end{tabular}

Incorporation of $\left[{ }^{14} \mathrm{C}\right]$ acetate. The results of experiments on the reactions of $\left.{ }^{[14} \mathrm{C}\right]$ acetate in extracts are given in Table 6 . The assay showed that extracts of the yeast grown under all conditions promoted the incorporation of major amounts of label from $\left[{ }^{14} \mathrm{C}\right]$ acetate into citrate, in the presence of oxaloacetate, and into malate, in the presence of glyoxylate. However, the incorporation into malate, in the presence of isocitrate, was much less in the succinate and citrate-grown yeast than in that grown on acetate.

\section{DISCUSSION}

The ability of $\mathbf{K}+$ yeasts to use succinate. A survey of the literature suggests that most $\mathbf{K}+$ yeasts can use succinic acid: that is, few yeasts seem unable to use succinate, but able to grow on citrate, fumarate or malate. Exceptions have been reported for Pichia farinosa, a strain of a Torulopsis species (Beech, 1957), Torulopsis pseudaeria (Zsolt, 1958), Rhodotorula crocea (Shifrine \& Phaff, 1956) and Saccharomycopsis guttulata (Shifrine \& Phaff, 1958). All the $\mathbf{K}+$ yeasts studied for the present work (Table 1) utilized succinate. However, the degree of agreement in the literature is more surprising than any disagreement. Apart from expected differences between strains, the answers obtained seem to depend greatly on the methods used, as is indicated by the results for Saccharomyces fermentati, S. lactis, and S. marxianus shown in Table 1. None the less previously published work supports the tentative generalizations already made about the 'Dekkeromyces' group and Saccharomyces 
mellis and $S$. rouxii (cf. Albritton, 1953; Barnett \& Ingram, 1955; Beech, 1957; Hedrick \& Burke, 1951; Miller \& Phaff, 1958; Nickerson \& Carroll, 1945; Niehaus, 1932; Phaff \& Knapp, 1956; Phaff, Miller \& Shifrine, 1956; Shehata, Mrak \& Phaff, 1955; Shifrine \& Phaff, 1956; Skinner \& Huxley, 1956; Teunisson, 1954; Wiles, 1954).

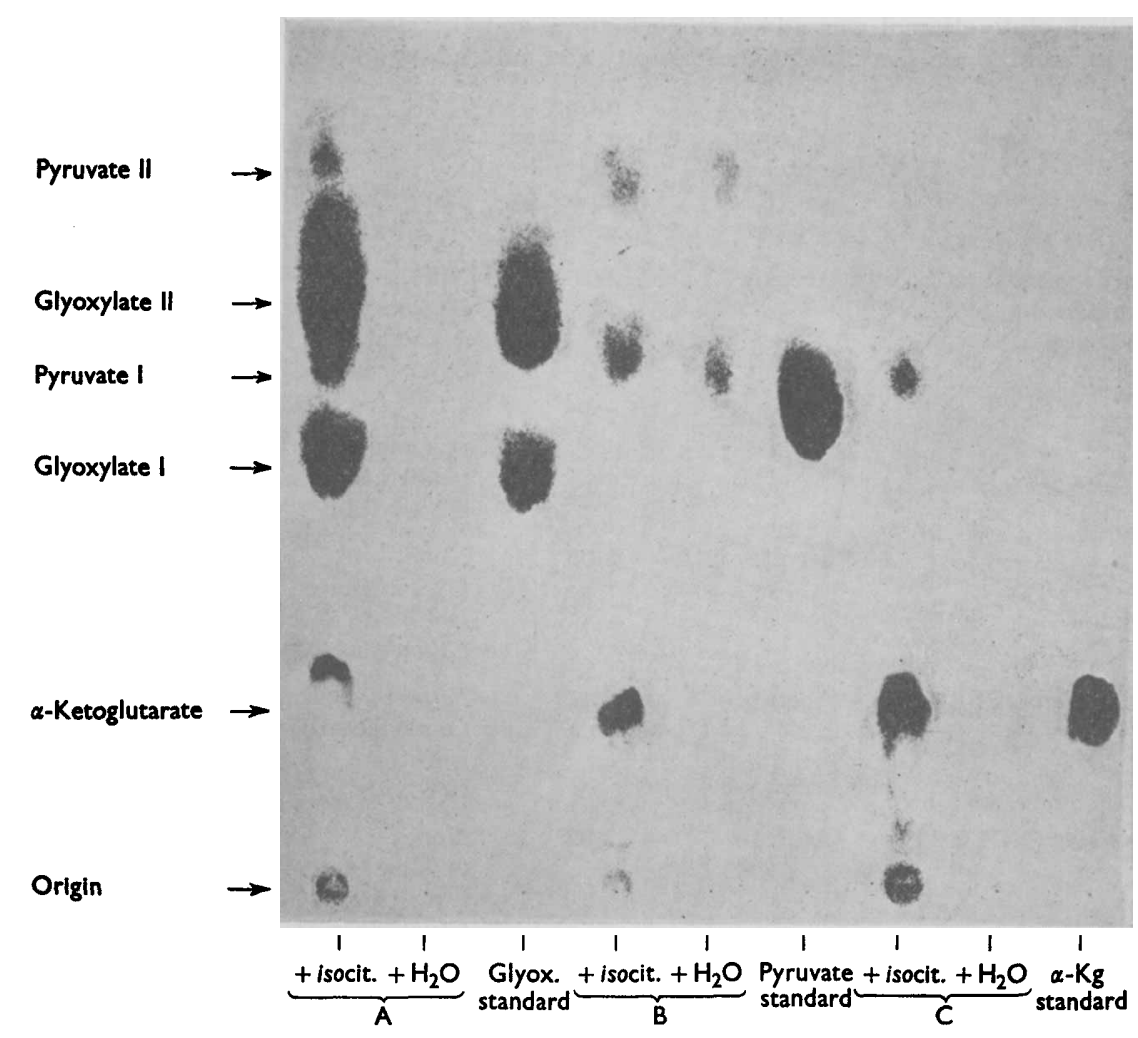

Fig. 3. Chromatogram of the 2:4-dinitrophenylhydrazones of the keto acids produced by extracts of Saccharomyces drosophilarum (CBS 2896) incubated alone and with isocitrate. Cells grown on acetate $(A)$, citrate $(B)$ or succinate $(C)$ as sole carbon sources.

The characterization of Saccharomyces cerevisiae. Of great interest are the yeasts classified as $\boldsymbol{S}$. cerevisiae, $\boldsymbol{S}$. carlsbergensis and similar organisms. They are of considerable industrial importance and there is much biochemical literature on the terminal respiratory mechanisms of $\boldsymbol{S}$. cerevisiae, usually as baker's yeast. There is much confusion about the biochemical characteristics of $S$. cerevisiae, and it is worth reviewing the facts at some length here. Baker's yeast is almost always $S$. cerevisiae (White, 1954; Nickerson, 1957; Pyke, 1958). Brewer's yeast is commonly so, though lager yeasts may be classified as $S$. carlsbergensis (Guilliermond, 1920; Lodder \& Kreger-van Rij, 1952; Thorne, 1957). The data given earlier agree with those of Kudriavzev (1954) in showing that $S$. cerevisiae is unable to grow on exogenous intermediates of the TCA cycle. This is also in agreement with observations on baker's and brewer's yeasts by other workers (e.g. Brandt, 1945; Krebs, 
Table 6. Reactions of $\left[{ }^{14} \mathrm{C}\right]$ acetate in extracts of yeasts

Extracts were prepared by crushing the yeast, grown on either acetate, succinate or citrate, in a Hughes Press and homogenizing the crushed material with 9 vol. of $0.9 \%$ $\mathrm{KCl}$. The suspensions were centrifuged at $15,000 \mathrm{~g}$ and $0.1 \mathrm{ml}$. of the supernatant solutions incubated with potassium phosphate, $\mathrm{MgCl}_{2}$, $\mathbf{A T P}$, coenzyme $\mathrm{A}$, glutathione, [14 C]acetate and additional substrates as indicated, at $30^{\circ}$ for $30 \mathrm{~min}$. At this time, $3 \mathrm{ml}$. hot absolute ethanol was added to each tube, and the ethanol soluble fractions were subsequently analysed by chromatography and autoradiography.

\begin{tabular}{|c|c|c|c|c|c|}
\hline & \multirow{2}{*}{$\begin{array}{l}\text { Carbon } \\
\text { source for } \\
\text { growth of } \\
\text { yeast }\end{array}$} & \multirow{2}{*}{$\begin{array}{c}\text { Protein } \\
\text { concentration } \\
\text { of original } \\
\text { extract } \\
(\mathrm{mg} . / \mathrm{ml} .)\end{array}$} & \multirow{2}{*}{$\begin{array}{l}\text { Substrate } \\
\text { added }\end{array}$} & \multicolumn{2}{|c|}{$\begin{array}{c}\text { Radioactivity } \\
\text { (counts/min.) } \\
\text { incorporated into }\end{array}$} \\
\hline & & & & Malate & Citrate \\
\hline \multirow[t]{3}{*}{$\begin{array}{l}\text { Saccharomyces } \\
\text { drosophilarum } \\
\text { (CBS 2896) }\end{array}$} & Acetate & $5 \cdot 46$ & $\begin{array}{l}\text { None } \\
\text { Oxaloacetate } \\
\text { isoCitrate } \\
\text { Glyoxylate }\end{array}$ & $\begin{array}{r}40 \\
60 \\
140,000 \\
187,000\end{array}$ & $\begin{array}{r}20 \\
159,000 \\
30 \\
10\end{array}$ \\
\hline & Succinate & $7 \cdot 27$ & $\begin{array}{l}\text { None } \\
\text { Oxaloacetate } \\
\text { isoCitrate } \\
\text { Glyoxylate }\end{array}$ & $\begin{array}{r}20 \\
40 \\
4,660 \\
64,800\end{array}$ & $\begin{array}{r}10 \\
160,000 \\
60 \\
60\end{array}$ \\
\hline & Citrate & $9 \cdot 05$ & $\begin{array}{l}\text { None } \\
\text { Oxaloacetate } \\
\text { isoCitrate } \\
\text { Glyoxylate }\end{array}$ & $\begin{array}{r}20 \\
60 \\
2,690 \\
38,800\end{array}$ & $\begin{array}{r}10 \\
89,100 \\
30 \\
30\end{array}$ \\
\hline S. acidifaciens (CBS 749) & Acetate & $\mathbf{2 \cdot 4 1}$ & $\begin{array}{l}\text { None } \\
\text { Oxaloacetate } \\
\text { isoCitrate } \\
\text { Glyoxylate }\end{array}$ & $\begin{array}{r}70 \\
650 \\
165,000 \\
194,000\end{array}$ & $\begin{array}{r}40 \\
189,000 \\
70 \\
40\end{array}$ \\
\hline S. cerevisiae (NCYC 231) & Acetate & 1.92 & $\begin{array}{l}\text { None } \\
\text { Oxaloacetate } \\
\text { isoCitrate } \\
\text { Glyoxylate }\end{array}$ & $\begin{array}{r}60 \\
180 \\
122,000 \\
151,000\end{array}$ & $\begin{array}{r}20 \\
105,000 \\
90 \\
40\end{array}$ \\
\hline
\end{tabular}

1949; Barron, Ardao \& Hearon, 1951; Slonimski, 1953; Krebs, 1954; Singer, Massey \& Kearney, 1957). An exception is the report by Krebs (1935) of baker's yeast respiring $\alpha$-ketoglutarate. Kilkenny \& Hinshelwood (1951) reported that five strains of $S$. cerevisiae (designated A, B, C, D, E) were able to grow on all the acids of the TCA cycle, except for strain $\mathrm{C}$ which did not grow on aconitic, citric, $\alpha$-ketoglutaric or oxaloacetic acids. Probably none of these five was in fact a strain of S. cerevisiae (Sir C. Hinshelwood, personal communication 1957). They were identified later at the Yeast Division of the CBS (Dr W. Ch. Slooff, personal communication 1957) as three strains of Hansenula anomala (A, B and D), one of Candida krusei $(\mathrm{C})$ and one $(\mathrm{E})$ of which the identity is in doubt. It would be more useful to regard $S$. cerevisiae as a $\mathbf{K}$ - yeast, and all strains capable of metabolizing exogenous TCA cycle intermediates would thus be excluded from this species. This would agree with the exclusion of Debaryomyces mandshuricus Naganishi, by Kudriavzev (1954) and of Zygosaccharomyces fermentati by both Kudriavzev (1954) and Phaff, Miller \& Shifrine (1956). These two were classified as $S$. cerevisiae by Lodder \& Kreger-van Rij (1952).

The tricarboxylic acid cycle in yeasts. The growth studies described here, and those 
of previous workers, show that yeasts can be classified as $\mathbf{K}+$ or $\mathbf{K}-$ by their ability to utilize for growth intermediates of the TCA cycle, but this classification does not imply that $\mathbf{K}$ - yeasts lack this cycle. Many $\mathbf{K}+$ yeasts cannot utilize all the cycle intermediates. Manometric data also differentiate $\mathbf{K}+$ and $\mathbf{K}-$ yeasts, but the oxidation of intermediates is variable and depends on the conditions of growth. Moreover, $\mathrm{K}+$ yeasts grown on acetate tend to have the respiratory behaviour of $\mathbf{K}$ - yeasts.

These findings can be explained by the existence of permeability barriers, which prevent free access of externally added substrates to intracellular enzyme systems. All the component reactions of the TCA cycle have been shown to occur in extracts of acetate-grown yeasts (for review, see Kornberg, 1959 $a$ ), and the cycle has been shown to be of major importance in acetate oxidation by baker's yeast, a typical $\mathrm{K}$-yeast (De Moss \& Swim, 1957). Comparison of the patterns of isotope incorporation from $\left[1: 2-{ }^{14} \mathrm{C}\right]$ acetate by a $\mathrm{K}+$ yeast (Saccharomyces drosophilarum) with those of $\mathbf{K}-$ yeasts (S. cerevisiae, $S$. acidifaciens) support this view. Although the procedure used in this work does not permit quantitative estimates to be made of the rate of incorporation of isotope from acetate, the distribution of radioactivity among the labelled components of each sample fairly reflects the time course of acetate incorporation. It is therefore significant that isotope from acetate was incorporated at early times only into intermediates of the TCA cycle and into amino acids (such as aspartate and glutamate) directly derived from them, and that these labelled compounds are found both in $\mathbf{K}+$ yeasts grown on succinate or citrate (which presumably metabolize these materials and acetate via the TCA cycle) and in acetate-grown $\mathbf{K}$-yeasts. Metabolism of acetate via the TCA cycle would result in an isotope content of succinate initially higher than that of malate: this was found to be the case (Table 3). Only in acetate-grown yeasts was this criterion not obeyed, and malate acquired isotope from acetate without passing through the stage of succinate. This indicated the operation of the glyoxylate cycle (Kornberg \& Krebs, 1957) under these conditions, in addition to that of the TCA cycle.

The glyoxylate cycle in yeasts. The key enzymes of the glyoxylate cycle are isocitratase (Smith \& Gunsalus, 1955; Olson, 1954) and malate synthetase (Wong \& Ajl, 1956), both of which have been shown to be present in extracts of baker's yeast (Olson, 1959; Kornberg, 1959b). The experiments reported in this paper confirm these findings. Extracts of acetate-grown yeasts, supplemented with necessary cofactors, catalysed the incorporation of isotope from acetate into malate if incubated with glyoxylate or isocitrate (Table 6), and contained high activities of malate synthetase and isocitratase (Table 5). Extracts of yeasts grown on succinate or citrate contained malate synthetase at $c .25 \%$ and $i s o c i t r a t a s e$ at $c .3 \%$ of the specific activities observed with acetate-grown yeasts. This indicates that the operation of the glyoxylate cycle in yeasts may be controlled by influencing the intracellular activity of isocitratase, as has also been found with Pseudomonas ovalis (Kornberg \& Lund, 1959) and Micrococcus denitrificans (Kornberg, Collins \& Bigley, 1960).

We are grateful to Professor Sir Hans Krebs, F.R.S., for his encouragement and interest, to Miss Patricia Lund for expert technical assistance, and to Dr H. B. Vickery (Connecticut Agricultural Experiment Station, New Haven, U.S.A.) for 
generous gifts of $\mathrm{L}_{\mathrm{a}}$-isocitrate. The work of one of us (H.L.K.) was supported, in part, by the Office of Scientific Research of the Air Research Development Command of the U.S. Air Force, through its European Office, under Contract No. AF 61 (514)-1180, and by the Rockefeller Foundation.

\section{REFERENCES}

Albritton, E. C. (1953). Standard Values in Nutrition and Metabolism. Dayton: McGregor and Werner.

BARnes, E. M. (1950). An investigation of antibacterial substances produced by microorganisms. D.Phil. Thesis, University of Oxford.

BarnetT, J. A. \& INGRAM, M. (1955). Technique in the study of yeast assimilation reactions. J. appl. Bact. $18,131$.

Barron, E. S. G., Ardao, M. I. \& Hearon, M. (1951). Regulatory mechanisms of cellular respiration. III. Enzyme distribution in the cell. Its influence on the metabolism of pyruvic acid by bakers' yeast. J. gen. Physiol. 34, 211.

BEECH, F. W. (1957). The incidence and classification of cider yeasts. Ph.D. Thesis, University of Bristol.

Brandt, K. M. (1945). The metabolic effect and the binding of carbon dioxide in baker's yeast. Acta physiol. scand. 10, suppl. XXX.

CaBeLL, V. J. (1955). The tricarboxylic acid cycle in the oxidative and synthetic metabolism of Klebsiella pneumoniae. J. Bact. 70, 23.

De Moss, J. A. \& SwIM, H. E. (1957). Quantitative aspects of the tricarboxylic acid cycle in baker's yeast. $J$. Bact. 74, 445 .

Dixon, G. H. \& Kornberg, H. L. (1959). Assay methods for key enzymes of the glyoxylate cycle. Biochem. J. 72, 3 P.

El Hawary, M. F. S. \& Thompson, R. H. S. (1953). Separation and estimation of blood keto acids by paper chromatography. Biochem. J. $53,340$.

Friedemann, T. E. \& Haugen, G. E. (1943). Pyruvic acid. II. The determination of keto acids in blood and urine. J. biol. Chem. 147, 415.

Guilliermond, A. (1920). The Yeasts. New York: Wiley.

HEDrick, L. R. \& Burke, G. C. (1951). Two new yeasts from Hawaiian fruit flies. Mycopathologia, 6, 92.

Hugres, D. E. (1951). A press for disrupting bacteria and other micro-organisms. Brit. J. exp. Path. 32, 97.

Ingram, M. (1958). Yeasts in food spoilage. In Cook, A. H.: The Chemistry and Biology of Yeasts. New York: Academic Press Inc.

Jones, M. E. \& Lipmann, F. (1955). Aceto-CoA-kinase. In Colowick, S. P. \& Kaplan, N. O. Methods in Enzymology, vol. 1. New York: Academic Press Inc.

KILKENNY, B. C. \& Hinshelwoon, C. (1951). The utilization of carbon sources by certain yeast strains. Proc. roy. Soc. B, 138, 375.

KIrsop, B. (1954). The National Collection of Yeast Cultures. J. Inst. Brew. 60, 210.

Kornaerg, $H$. L. (1958). The metabolism of $\mathrm{C}_{2}$ compounds in micro-organisms. 1. The incorporation of $\left[{ }^{2-14} \mathrm{C}\right]$ acetate by Pseudomonas fluorescens, and by a Corynebacterium, grown on ammonium acetate. Biochem. J. 68, 535 .

Kornberg, H. L. (1959a). Aspects of terminal respiration in micro-organisms. Annu. Rev. Microbiol. 13, 49.

KorNBERG, H. L. (1959b). Synthesis of cell constituerits from acetate via the glyoxylate cycle. Proc. IVth int. Congr. Biochem. 13, 25.

Kornberg, H. L., Collins, J. F. \& (in part) Bigley, D. (1960). The influence of growth substrates on metabolic pathways in Micrococcus denitrificans. Biochim. biophys. Acta, 39, 13.

KornBerg, H. L. \& KreBs, H. A. (1957). Synthesis of cell constituents from $\mathrm{C}_{2}$-units by a modified tricarboxylic acid cycle. Nature, Lond. 179, 988.

KorNBERG, H. L. \& LUND, P. (1959). Influence of growth substrates on levels of glyoxylate cycle enzymes in Pseudomonas ovalis Chester. Biochem. J. 72, 33 P. 


\section{Use of TCA cycle acids by yeasts}

Kornberg, H. L. \& MADSEN, N. B. (1957). Synthesis of $\mathbf{C}_{4}$-dicarboxylic acids from acetate by a 'glyoxylate bypass' of the tricarboxylic acid cycle. Biochim. biophys. Acta, 24, 651 .

Kornberg, H. L. \& Madsen, N. B. (1958). The metabolism of $\mathrm{C}_{2}$ compounds in microorganisms. 3. Synthesis of malate from acetate via the glyoxylate cycle. Biochem. $J$. $68,549$.

KreiBs, H. A. (1935). Metabolism of amino-acids. III. Deamination of amino acids. Biochem. J. 29, 1620.

KrEBs, H. A. (1949). The occurrence of the tricarboxylic acid cycle in yeast. Abstr. 1st int. Congr. Biochem. p. 836.

KreBsi, H. A. (1954). The tricarboxylic acid cycle. In Greenberg, D. M.: Chemical Pathroays of Metabolism. New York: Academic Press Inc.

Kudriavzev, V. I. (1954). The Systematics of Yeasts. Moscow: Academy of Sciences.

Leberle, H. \& Wilx, H. (1910). Beiträge zur Kenntnis der Gattung Mycoderma. Z Zbl. Bakt. (2 Abt.), 28, 1.

LodDer, J. \& Kreger-van RIJ, N. J. W. (1952). The Yeasts. A Taxonomic Study. Amsterdam: North Holland Publishing Co.

Mackie, T. J. \& MCCaRtney, J. E. (1956). Handbook of Practical Bacteriology, 9th ed. Edinburgh: E. and S. Livingstone.

Mruler, M. W. \& Phaff, H. J. (1958). A comparative study of the apiculate yeasts. Mycopathologia, 10, 113.

Nickerson, W. J. (1957). Cytology and cytochemistry of baker's yeast. In Roman, W.: Yeasts. The Hague: Junk.

Nickerson, W. J. \& CARroll, W. R. (1945). On the metabolism of Zygosaccharomyces. Arch. Biochem. 7, 257.

Nieraus, C. J. G. (1932). Untersuchungen über Apiculatushefen. Zbl. Bakt. (2 Abt.), 87, 97.

OkUNUKI, K. (1931). Beiträge zur Kenntnis der rosafarbigen Sprosspilze. Jap. J. Bot. 5, 285.

Olson, J. A. (1954). The $d$-isocitric lyase system: the formation of glyoxylic and succinic acids from $d$-isocitric acid. Nature, Lond., 174, 695.

Olson, J. A. (1959). The purification and properties of yeast isocitric lyase. J. biol. Chem. 234, 5.

Phaff, H. J. \& Knapp, E. P. (1956). The taxonomy of yeasts found in exudates of certain trees and other natural breeding sites of some species of Drosophila. Antonie van Leeuwenhoek J. Microbiol. Serol. 22, $11 \%$.

Phaff, H. J., Mruler, M. W. \& Shifrine, M. (1956). The taxonomy of yeasts isolated from Drosophila in the Yosemite region of California. Antonie van Leewrwenhoek J. Microbiol. Serol. 22, 145.

Pyke, M. (1958). The technology of yeast. In Cook, A. H.: The Chemistry and Biology of Yeasts. New York: Academic Press Inc.

Shehata, A. M. E. T., Mrak, E. M. \& Phaff, H. J. (1955). Yeasts isolated from Drosophila and from their suspected feeding places in Southern and Central California. Mycologia, 47, 799 .

Shifrine, M. \& Phaff, H. J. (1956). The association of yeasts with certain bark beetles. Mycologia, 48, 41.

ShIFrine, M. \& Phaff, H. J. (1958). On the isolation, ecology and taxonomy of Saccharomycopsis guttulata. Antonie van Leeuwenhoek J. Microbiol. Serol. 24, 198.

Singer, T. P., Massey, V. \& Krarney, E. B. (1957). Studies on succinic dehydrogenase. V. Isolation and properties of the dehydrogenase from baker's yeast. Arch. Biochem. 69, 405.

Skinner, C. E. \& Huxuey, M. J. (1956). Rhodotorula glutinis. Mycologia, 48, 371.

SLonrmskr, P. (1953). Recherches sur la formation des enzymes respiratoires chez la levure. Actualités biochim. 17, 1.

Smite, R. A. \& Gunsalus, I. C. (1955). Distribution and formation of isocitratase. Nature, Lond. 175, 774. 
Stadtmann, E. R., Novel.u, G. D. \& Lipmans, F. (1951). Coenzyme A function in and acetyl transfer by the phosphotransacetylase system. J. biol. Chem. 191, 365 .

Teunisson, D. J. (1954). Yeasts from freshly combined rough rice stored in a sealed bin. Appl. Microbiol. 2, 215.

Thorne, R. S. W. (1957). Brewer's yeasts. In Roman, W.: Yeasts. The Hague: Junk.

Umbreit, W. W., Burris, R. H. \& Stauffer, J. F. (1949). Manometric Techniques and Tissue Metabolism, 2nd ed. Minneapolis: Burgess Publishing Co.

Whrte, J. (1954). Yeast Technology. London: Chapman and Hall.

WickerhaM, L. J. (1951). Taxonomy of yeasts. Tech. Bull. U.S. Dep. Agric. no. 1029.

WICKERHAM, L. J. (1955). New materials and procedures for genetic studies of yeasts. Nature, Lond. 176, 22.

Wickerham, L. J. \& Burton, K. A. (1948). Carbon assimilation tests for the classification of yeasts. J. Bact. 56,863 .

Wickerham, L. J. \& Burton, K. A. (1956a). Hybridization studies involving Saccharomyces lactis and Zygosaccharomyces ashbyi. J. Bact. 71, 290.

Wickerham, L. J. \& Burton, K. A. (1956b). Hybridization studies involving Saccharomyces fragilis and Zygosaccharomyces dobzhanskii. J. Bact. 71, 296.

WiLEs, A. E. (1954). The wild yeast problem as a facet of brewing technology. Wallerstein Labs Commun. 17, 259.

Winzler, R. J. \& Baumberger, J. P. (1938). The degradation of energy in the metabolism of yeast cells. J. cell. comp. Physiol. $12,183$.

Wong, D. T. O. \& AJL, S. J. (1956). Conversion of acetate and glyoxylate to malate. J. Amer. chem. Soc. 78, 3230.

Zsolt, J. (1958). Torulopsis pseudaeria nov.spec., a new yeast from soil. Antonie van Leeuwenhoek J. Microbiol. Serol. 24, 210. 